\title{
Planning and Developing a Web-Based Intervention for Active Surveillance in Prostate Cancer; An Integrated Self-Care Programme for Managing Psychological Distress
}

\author{
Stephanie Hughes ( $\square$ sh3r11@soton.ac.uk) \\ University of Southampton https://orcid.org/0000-0003-4801-8245
}

Angelos P. Kassianos

University College London

Hazel Everitt

University of Southampton

\section{Beth Stuart}

University of Southampton

Rebecca Band

University of Southampton

\section{Methodology}

Keywords: Prostate cancer, active surveillance, psychological distress, online intervention, web-based intervention, digital intervention, self-management, anxiety, person-based approach

Posted Date: February 1st, 2022

DOl: https://doi.org/10.21203/rs.3.rs-1228386/v1

License: (9) (1) This work is licensed under a Creative Commons Attribution 4.0 International License. Read Full License 


\section{Abstract}

\section{Objectives:}

To outline the planning, development and optimisation of a psycho-educational behavioural intervention for patients on active surveillance for prostate cancer. The intervention aimed to support men manage active surveillance related psychological distress.

\section{Methods:}

The person-based approach (PBA) was used as the overarching guiding methodological framework for intervention development. Evidence-based methods were incorporated to improve robustness. The process comprised of the following four components:

- A systematic review and meta-analysis of depression and anxiety in prostate cancer

- A cross-sectional survey on depression and anxiety in active surveillance

- A review of existing interventions in the field

- A qualitative study with the target audience

The purpose of this paper is to bring these components together and describe how they facilitated the establishment of key guiding principles and a logic model, which underpinned the first draft of the intervention.

\section{Results:}

The prototype intervention, named PROACTIVE, consists of six internet-based sessions run concurrently with three group support sessions. The sessions cover the following topics: lifestyle (diet and exercise), relaxation and resilience techniques, talking to friends and family, thoughts and feelings, daily life (money and work), and includes information about prostate cancer and active surveillance.

\section{Conclusions:}

The planning and development process is key to successful delivery of an appropriate, accessible and acceptable intervention. The PBA strengthened the intervention by drawing on target-user experiences to maximise acceptability and user engagement. This meticulous description in a clinical setting using this rigorous but flexible method is a useful demonstration for others developing similar interventions.

\section{Trial registration and ethical approval:}

NRES Committee South Central - Oxford A. REC reference: 11/SC/0355

IRAS project ID: 83650

\section{Key Messages Regarding Feasibility}

- At the start of this process there were uncertainties around the feasibility of:

- Reaching and recruiting the target group (men on active surveillance for prostate cancer) 
- Creating an accessible and acceptable intervention

- Key feasibility findings:

- Men on active surveillance for prostate cancer would like additional support, and are willing to take part in online and group-based sessions

- The research activities carried out in the intervention planning and development phases have optimised the acceptability of the proposed intervention.

\section{Background}

Prostate cancer prevalence is high in the UK(1), and affects around one in eight men(2). Treatment options include surgery, radiotherapy and hormone therapy, but for men with localised, low-risk prostate cancer, active surveillance (AS), a pathway that involves monitoring biological markers of the disease for progression, is also an option. AS aims to reduce overtreatment and comes without the unwanted side effects of interventional treatment, such as urinary incontinence and erectile dysfunction (3). However, research has shown AS may have a negative impact on psychological wellbeing with patients experiencing heightened levels of anxiety(4-6), illness uncertainty, hopelessness(7) and distress(8).

Few studies have explored the unmet psychological needs of men on AS and ways in which wellbeing could be improved(9), and to our knowledge there are no existing interventions available to support men on AS. The limited qualitative evidence suggests men on AS find AS related information inadequate and inconsistent(9), experience unmet psychological and emotional needs(9), and spousal support is important for AS acceptance(10). Furthermore, anxiety and uncertainty are two key reasons men choose to discontinue AS and pursue interventional treatments in the absence of changes to tumour status $(11,12)$, risking treatment side effects. Research in the area of AS related psychological wellbeing is vital to ensure patients have the information and tools that will allow them to better cope with this treatment pathway.

Best practice guidance recommends taking a 'person-based' approach (PBA) when developing behavioural interventions(13). The PBA is an established method used to optimise interventions, providing a clear process to ground interventions in the perspectives and psychosocial context of the target user group. The PBA recommends comprehensive qualitative research with the target user group to explore their experiences and create a picture of the challenges they face, and in turn the things that are likely to influence a target behaviour. Exploration of the key beliefs target users hold, for example, about their condition, its management or treatment, is important to gain an understanding of what might facilitate or prevent change. Taking this approach, the target users' needs and preferences can influence the content, structure and overall design of the intervention, ultimately improving the intervention's feasibility, acceptability and user engagement(14).

This paper describes four previously published research activities, bringing them together to demonstrate how they contributed to the planning and development process of PROACTIVE, a psycho-educational intervention for men with localised prostate cancer on active surveillance, consisting of parallel group-support and web-based sessions. It aims to describe the methodology needed to plan such an intervention, presenting a demonstration of how to develop an intervention using a PBA.

Using the Person-based approach to guide PROACTIVE planning 
The PBA is flexible and non-prescriptive, and can be utilised alongside evidence-based approach methods and theory. The PBA provides an established methodological framework for the intervention planning process(13). The approach consists of two key stages. The first involves gathering information from the target audience to gain an insight into what is wanted and needed, giving the researchers a deeper appreciation of the psychosocial context of the audience. This is an iterative process used to continually refine the intervention to promote acceptability, and to encourage adherence and engagement.

The second stage is the creation of 'key guiding principles'. These consist of a) key intervention design objectives and b) key distinctive features of the intervention needed to achieve objectives. These principles aim to keep the design and development process on track by providing the research team with a summary of objectives to be referred to at each stage of the process.

The planning process commenced with a systematic review and meta-analysis of depression and anxiety in PCa. This was an evidence gathering activity aiming to improve understanding about the prevalence and magnitude of psychological distress in men with PCa (not specific to AS).

Using the PBA framework, the following activities were subsequently conducted to facilitate our understanding of: psychological distress specific to those on the AS pathway; the interventions that have been trialled previously; and the supportive care needs of the target audience:

- A cross-sectional survey on depression and anxiety in active surveillance

- A review of existing interventions in the field

- A qualitative study with the target audience

These components facilitated the creation of key guiding principles and a logic model to guide the intervention development.

Table 1 below shows the stages recommended by the PBA for intervention planning and development (columns 1 and 2) alongside an overview of the development of PROACTIVE (column 3) to show how the PBA process was implemented. Each activity will be described in depth in the next section. 
Table 1

PBA implementation in PROACTIVE

\begin{tabular}{|c|c|c|c|}
\hline $\begin{array}{l}\text { Stage of } \\
\text { intervention } \\
\text { development } \\
\text { and evaluation }\end{array}$ & $\begin{array}{l}\text { Specific PBA activities useful at each } \\
\text { stage }\end{array}$ & $\begin{array}{l}\text { PROACTIVE planning, } \\
\text { development and } \\
\text { optimisation }\end{array}$ & Additional activities \\
\hline $\begin{array}{l}\text { 1. Intervention } \\
\text { planning }\end{array}$ & $\begin{array}{l}\text { - Synthesise previous qualitative } \\
\text { studies of user experiences of similar } \\
\text { interventions } \\
\text { - Carry out qualitative research to elicit } \\
\text { user views of the planned behaviour } \\
\text { changes and intervention (including } \\
\text { relevant previous experience, barriers } \\
\text { and facilitators) }\end{array}$ & $\begin{array}{l}\text { - Review of existing } \\
\text { interventions in the } \\
\text { field } \\
\text { - Qualitative study }\end{array}$ & $\begin{array}{l}\text { - A systematic review and } \\
\text { meta-analysis of } \\
\text { depression and anxiety in } \\
\text { prostate cancer (evidence- } \\
\text { based approach activity) }\end{array}$ \\
\hline $\begin{array}{l}\text { 2. Intervention } \\
\text { design }\end{array}$ & $\begin{array}{l}\text { - Create guiding principles, } \\
\text { comprising: a) Key intervention design } \\
\text { objectives b) Key distinctive features } \\
\text { of the intervention needed to achieve } \\
\text { objectives }\end{array}$ & $\begin{array}{l}\text { - Use themes from } \\
\text { qualitative study to } \\
\text { identify key issues, } \\
\text { needs and challenges } \\
\text { Proactive must } \\
\text { address } \\
\text { - Create guiding } \\
\text { principles }\end{array}$ & \\
\hline $\begin{array}{l}\text { 3. Intervention } \\
\text { optimisation } \\
\text { and evaluation } \\
\text { of } \\
\text { acceptability } \\
\text { and feasibility }\end{array}$ & $\begin{array}{l}\text { - Elicit and observe user reactions to } \\
\text { every intervention element (e.g. using } \\
\text { thinkaloud techniques), iteratively } \\
\text { modifying intervention to optimise } \\
\text { acceptability and feasibility } \\
\text { - Carry out detailed longitudinal mixed } \\
\text { methods case studies of independent } \\
\text { intervention usage }\end{array}$ & $\begin{array}{l}\text { - Create Proactive } \\
\text { prototype, conduct } \\
\text { think aloud interviews } \\
\text { and modify the } \\
\text { intervention } \\
\text { accordingly }\end{array}$ & \\
\hline
\end{tabular}

\section{Methods}

\section{Intervention Planning}

\section{Review of the literature}

Systematic review and meta-analysis of depression and anxiety in prostate cancer

Aim:

An evidence-based approach activity to systematically review literature around depression and anxiety prevalence in patients with prostate cancer (published elsewhere)(4).

Methods: 
Due to a lack of previous research about depression and anxiety in men specifically on the AS pathway this review included men on other PCa treatment pathways. After de-duplication, 1130 articles were screened for eligibility, and 27 full journal articles were included giving a total sample size of 4494 prostate cancer patients.

\section{Results:}

Anxiety and depression were highly prevalent, and levels varied throughout the course of the illness and according to treatment status. A pattern of depression and anxiety was identified showing rates were highest after diagnosis before treatment, (depression: $17.27 \%$ (95\% Cl 15.06\% to $19.72 \%)$ ), (anxiety: $27.04 \%$ (95\% Cl 24.26\% to 30.01\%)), lowered during treatment (depression: $14.70 \%$ (95\% Cl 11.92\% to 17.99\%)), (anxiety: $15.09 \%$ (95\% Cl 12.15\% to $18.60 \%)$ ), and then raised again when treatment was complete (depression: $18.44 \%$ (95\% Cl $15.18 \%$ to $22.22 \%)$ ), (anxiety: $18.49 \%$ (95\% Cl $13.81 \%$ to $24.31 \%)$ ).

\section{Relevance to PROACTIVE planning:}

Of the 27 articles included, only 4 involved AS patients(15-18). The upper depression and anxiety prevalence rates reported within these articles were high, $17 \%$ and $21 \%$ respectively, indicating the need for further research into the psychological impact of AS, and an investigation into the use of a support tool.

\section{Cross-sectional survey study}

Cross-sectional assessment of depression and anxiety prevalence in prostate cancer patients undergoing AS

\section{Aim:}

To further explore the issue of heightened anxiety and depression in men with PCa, and provide a broader picture specific to AS, the research team conducted a cross-sectional assessment aiming to explore depression and anxiety prevalence specifically in prostate cancer patients undergoing AS. The full study is published elsewhere(5).

\section{Methods:}

313 men being managed by AS for PCa across 7 UK urology centres were recruited. The primary outcome was the Hospital Anxiety and Depression Scale (HADS)(19). The survey collected demographic data (age, employment, relationship, ethnic and educational status), to allow for cross-tabulation with anxiety and depression scores.

\section{Results:}

Results from this survey indicated a clinical depression prevalence of $12.5 \%$, and clinical anxiety prevalence of $23 \%$ measured by the HADS. The results show a more than doubled depression prevalence, and almost tripled anxiety prevalence in men on AS for prostate cancer compared to men of a similar age in the general population (6\% and $8 \%$ respectively(20)). Divorce was the only demographic predictor of higher anxiety and depression(5), indicating the family environment may need further investigation also.

\section{Implications for PROACTIVE:}

With the combined results from the systematic review and cross-sectional assessment indicating elevated levels of anxiety and depression, the research team concluded the levels of distress in men on AS for PCa needs to be addressed. 


\section{Review of existing interventions in the field}

To gain an insight into whether informational, psychological, emotional or cognitive interventions can positively impact men with prostate cancer, the research team conducted a narrative literature review of supportive psychological interventions within prostate cancer (published elsewhere)(21). Ideally this review would have focussed on AS patients, however, due to a paucity of interventions in this area, interventions for PCa not exclusive to AS were included. The interventions were categorised by delivery mode: delivered in a group-based environment, delivered over the phone, delivered over the internet or delivered by other means. Intervention components and intervention effectiveness were considered in tandem (listed below in Table 2) to enhance understanding of the components that may be effective in a new intervention. See Table 2 for a summary of the self-care interventions and the implications for PROACTIVE.

Table 2: Self-care psychological interventions targeting prostate cancer patients 


\begin{tabular}{|c|c|c|c|c|c|}
\hline Author(s) & $\begin{array}{l}\text { Mode of } \\
\text { delivery }\end{array}$ & $\begin{array}{l}\text { Intervention } \\
\text { description }\end{array}$ & $\begin{array}{l}\text { Intervention } \\
\text { components }\end{array}$ & $\begin{array}{l}\text { Results / } \\
\text { Effectiveness / } \\
\text { points of interest }\end{array}$ & $\begin{array}{l}\text { Implications for } \\
\text { PROACTIVE }\end{array}$ \\
\hline $\begin{array}{l}\text { Parker et } \\
\text { al (2009) } \\
(22)\end{array}$ & $\begin{array}{l}\text { Group } \\
\text { based } \\
\text { environment }\end{array}$ & $\begin{array}{l}\text { Pre-surgical } \\
\text { stress } \\
\text { management } \\
\text { programme } \\
\text { for men } \\
\text { undergoing } \\
\text { radical } \\
\text { prostatectomy }\end{array}$ & $\begin{array}{l}2 \times 90 \text { minute } \\
\text { sessions that } \\
\text { involved: } \\
\text { - Learning } \\
\text { relaxation } \\
\text { skills } \\
\text { - Guided } \\
\text { imaginary } \\
\text { rehearsals of } \\
\text { surgery day } \\
\text { - Discussion } \\
\text { about fears } \\
\text { and } \\
\text { implementation } \\
\text { of coping } \\
\text { strategies. } \\
\text { 2x booster } \\
\text { sessions: on the } \\
\text { morning of surgery; } \\
\text { and } 48 \text { hrs post } \\
\text { surgery }\end{array}$ & $\begin{array}{l}\text { Significantly less } \\
\text { mood disturbance, } \\
\text { cancer related } \\
\text { worries and } \\
\text { physical side } \\
\text { effects than } \\
\text { controls. Effects } \\
\text { maintained at } 12 \\
\text { months. } \\
221 \text { potential } \\
\text { participants } \\
\text { approached, } 159 \\
\text { took part. }\end{array}$ & $\begin{array}{l}\text { Level of uptake } \\
\text { suggests PCa } \\
\text { patients are } \\
\text { willing to take } \\
\text { part in self-care } \\
\text { interventions to } \\
\text { improve } \\
\text { psychological } \\
\text { wellbeing. }\end{array}$ \\
\hline $\begin{array}{l}\text { Penedo et } \\
\text { al }(2004 \& \\
2006)(23, \\
24)\end{array}$ & $\begin{array}{l}\text { Group } \\
\text { based } \\
\text { environment }\end{array}$ & $\begin{array}{l}\text { Cognitive } \\
\text { behavioural } \\
\text { stress } \\
\text { management } \\
\text { intervention } \\
\text { with men who } \\
\text { had received } \\
\text { either radical } \\
\text { prostatectomy } \\
\text { or } \\
\text { radiotherapy } \\
\text { for PCa }\end{array}$ & $\begin{array}{l}10 \text { week } \\
\text { intervention with } 2 \\
\text { hour weekly } \\
\text { sessions involving: } \\
\text { - Implementing } \\
\text { relaxation } \\
\text { techniques } \\
\text { - Utilising } \\
\text { techniques } \\
\text { such as } \\
\text { identifying } \\
\text { distorted } \\
\text { thoughts } \\
\text { - Goal setting } \\
\text { - Utilising social } \\
\text { support. }\end{array}$ & $\begin{array}{l}\text { Significant } \\
\text { improvements in } \\
\text { both general and } \\
\text { PCa specific quality } \\
\text { of life compared to } \\
\text { controls. }\end{array}$ & $\begin{array}{l}\text { In PCa patients } \\
\text { relaxation } \\
\text { interventions are } \\
\text { both well } \\
\text { received and } \\
\text { clinically } \\
\text { effective. }\end{array}$ \\
\hline $\begin{array}{l}\text { Carlson et } \\
\text { al }(2003 \& \\
2007)(25, \\
26)\end{array}$ & $\begin{array}{l}\text { Group } \\
\text { based } \\
\text { environment }\end{array}$ & $\begin{array}{l}\text { Standardised } \\
\text { Mindfulness } \\
\text { Based Stress } \\
\text { Reduction } \\
\text { (MBSR) } \\
\text { course }\end{array}$ & $\begin{array}{l}8 \text { weekly sessions } \\
\text { incorporating: } \\
\text { - Relaxation } \\
\text { - Meditation } \\
\text { - Gently yoga } \\
\text { - Daily home } \\
\text { practice } \\
\text { (Note: Recruits not } \\
\text { exclusively PCa). }\end{array}$ & $\begin{array}{l}\text { Significant } \\
\text { improvements in } \\
\text { sleep, stress, } \\
\text { anxiety, mood and } \\
\text { fatigue. }\end{array}$ & $\begin{array}{l}\text { Results were not } \\
\text { stratified by } \\
\text { disease type, so } \\
\text { hard to draw any } \\
\text { strong } \\
\text { implications for } \\
\text { PROACTIVE, } \\
\text { however, the } \\
\text { study findings } \\
\text { do support the } \\
\text { notion of group- } \\
\text { based support } \\
\text { for cancer } \\
\text { patients. }\end{array}$ \\
\hline $\begin{array}{l}\text { Templeton } \\
\& \text { Coates }\end{array}$ & $\begin{array}{l}\text { Group } \\
\text { based } \\
\text { environment }\end{array}$ & $\begin{array}{l}\text { Educational } \\
\text { intervention }\end{array}$ & $\begin{array}{l}\text { Brief, group-based, } \\
\text { nurse-led single } \\
\text { session for men }\end{array}$ & $\begin{array}{l}\text { Compared to } \\
\text { controls, significant } \\
\text { improvements in }\end{array}$ & $\begin{array}{l}\text { Intervention } \\
\text { effectiveness } \\
\text { may not be dose }\end{array}$ \\
\hline
\end{tabular}

Page 8/26 
being treated with hormone therapy for PCa.

Participants were provided with an information booklet. general and $\mathrm{PCa}$ specific quality of life, PCa knowledge and satisfaction with care.

related, and

short

interventions

may be as

effective as

more time

consuming programmes.

Information

provision is

valued by $\mathrm{PCa}$

patients.

The participants

in this trial were

receiving

hormone

treatment and

those on AS may feel differently.

$\begin{array}{lll}\text { Berglund } & \text { Group } & \text { Psychosocial } \\ \text { et al } & \text { based } & \text { rehabilitation } \\ \text { (2007) } & \text { environment } & \end{array}$
(28)

7-week group based intervention.

3 arms; information arm, physical activity arm, combined arm, plus a control group.

- Information arm led by PCa nurse and participants received information about what $\mathrm{PCa}$ is, treatment options, side effects, and methods of dealing with urinary and erectile dysfunction.

- Physical activity arm led by physiotherapist and focussed on increasing daily exercise.

- Combined arm received both

$\begin{array}{lll}\text { Lepore et } & \text { Group } & \text { Educational } \\ \text { al (2003) } & \text { based } & \text { intervention } \\ (29) & \text { environment } & \end{array}$

$\begin{array}{ll}\begin{array}{l}\text { 3 groups, } \\ \text { intervention, }\end{array} & \begin{array}{l}\text { Both intervention } \\ \text { arms showed } \\ \text { intervention plus } \\ \text { discussion, control } \\ \text { group. }\end{array} \\ \begin{array}{l}\text { impricant } \\ \text { PCa knowledge and } \\ \text { experienced less }\end{array} \\ \text { Intervention } & \begin{array}{l}\text { sexual dysfunction } \\ \text { involved 6 1-hour }\end{array} \\ \text { compared to the } \\ \text { control group. No } \\ \text { sessions involving: } & \begin{array}{l}\text { significant } \\ \text { improvements in } \\ \text { depression. }\end{array}\end{array}$

No significant improvements in anxiety, depression or quality of life.
Unclear why the intervention was unsuccessful, perhaps information needs to be combined with relaxation/stress management techniques. 
- Prostate cancer biology information

- Treatment options

- Managing side effects

- Diet and nutrition

- Stress, coping and relaxation.

\begin{tabular}{|c|c|c|}
\hline $\begin{array}{l}\text { Bailey et } \\
\text { al }(2004) \\
(30)\end{array}$ & Telephone & $\begin{array}{l}\text { Intervention to } \\
\text { manage } \\
\text { uncertainty }\end{array}$ \\
\hline
\end{tabular}

This was designed for men on watchful waiting. 5 brief telephone consultations with a male PCa nurse, with week-long intervals. Telephone consultations around:

- Re-framing negative thoughts

- Managing uncertainty

- Accepting watchful waiting

\section{Chambers Telephone} et al (2013)

(31)

\section{Psycho- educational intervention}

5 brief telephone consultations with PCa patients around:

- Cognitive reframing

- PCa education

- Management of side effects

- Management of stress

- Developing problem solving skills
Significant improvements in quality of life and uncertainty management compare to controls.
This study limited by high homogeneity in the sample, and watchful waiting patients may be different to AS patients.

\section{Significant} improvements in mental health and cancer related distress in younger patients with higher levels of education and income, but not in the rest of the sample.
5 week online

Kazer et al Internet (2011)

(32)

Intervention to
manage
uncertainty
intervention named "Alive and Well" for men on AS. Components included:

- Cognitive reframing of negative thoughts

- PCa \& AS information

\section{Significant} improvement in 8 of the 12 quality of life subscales measured at the end of the intervention.
An online-only intervention improve quality of life in men on AS.
Heterogeneous sample compared to Bailey et al (2004), and large sample recruited from multiple centres. Indicates telephone support may not be effective for some groups of PCa patients.

Page 10/26 
- Lifestyle

advice

- Tailored emails

\begin{tabular}{|c|c|c|c|c|c|}
\hline $\begin{array}{l}\text { Osei et al } \\
(2013) \\
(33)\end{array}$ & Internet & $\begin{array}{l}\text { Intervention to } \\
\text { improve } \\
\text { quality of life }\end{array}$ & $\begin{array}{l}6 \text { week online } \\
\text { intervention for men } \\
\text { radically treated for } \\
\text { PCa involving: } \\
\text { - Online support } \\
\text { forum } \\
\text { - PCa } \\
\text { information } \\
\text { - Support } \\
\text { managing side } \\
\text { effects. }\end{array}$ & $\begin{array}{l}\text { Significant } \\
\text { improvements in } \\
\text { quality of life, but } \\
\text { not maintained at } \\
\text { follow-up. }\end{array}$ & $\begin{array}{l}\text { Support may } \\
\text { need to be more } \\
\text { long term to } \\
\text { improve } \\
\text { outcomes } \\
\text { beyond the study } \\
\text { timeframe. }\end{array}$ \\
\hline $\begin{array}{l}\text { Weber et } \\
\text { al (2004) } \\
(34)\end{array}$ & $\begin{array}{l}\text { Other - } \\
\text { dyadic } \\
\text { support }\end{array}$ & $\begin{array}{l}\text { Social support } \\
\text { intervention }\end{array}$ & $\begin{array}{l}\text { Post-radical } \\
\text { prostatectomy } \\
\text { patients paired with } \\
\text { men who had the } \\
\text { same surgery } 5 \\
\text { years previously. } \\
\text { Men in the } \\
\text { intervention arm } \\
\text { met with long term } \\
\text { survivors once a } \\
\text { week for } 8 \text { weeks. }\end{array}$ & $\begin{array}{l}\text { Men in intervention } \\
\text { arm reported } \\
\text { significantly lower } \\
\text { levels of depression } \\
\text { and significantly } \\
\text { higher levels of self- } \\
\text { efficacy compared } \\
\text { to controls. High } \\
\text { attrition rate - all } 8 \\
\text { sessions attended } \\
\text { by every } \\
\text { intervention arm } \\
\text { participant. }\end{array}$ & $\begin{array}{l}\text { Dyadic support } \\
\text { well adhered to. } \\
\text { Support from } \\
\text { men who have } \\
\text { had similar } \\
\text { experiences can } \\
\text { be effective in } \\
\text { improving } \\
\text { psychological } \\
\text { outcomes. }\end{array}$ \\
\hline
\end{tabular}

\section{Qualitative study with a sample of the target audience}

Aim:

The research team carried out a qualitative study with the aim of gaining a more in-depth and specific understanding of the supportive care requirements of prostate cancer patients being managed with AS. The full study is published elsewhere(8), and an overview is presented below.

\section{Methods:}

20 men on active surveillance were recruited from the prostate cancer clinic at Southampton General Hospital. Semi-structured qualitative interviews were conducted and analysed inductively using thematic analysis.

\section{Results:}

Table 3 shows the key findings that emerged from the data. In summary, the men reported high levels of emotional distress, a lack of knowledge about their condition or how to self-manage it, and a desire for more information and support(8).

Table 3: Key findings from the qualitative study 


\begin{tabular}{|c|c|c|}
\hline Theme & Description & Quote \\
\hline $\begin{array}{l}\text { Emotional } \\
\text { Distress }\end{array}$ & $\begin{array}{l}\text { All of the men } \\
\text { interviewed } \\
\text { showed increased } \\
\text { levels of } \\
\text { emotional distress } \\
\text { to varying degrees } \\
\text { due to being } \\
\text { on active } \\
\text { surveillance. }\end{array}$ & $\begin{array}{l}\text { "You are told that you have cancer but that it's nothing to worry about and } \\
\text { that all they are going to do is watch it to see how it grows. That just } \\
\text { doesn't make sense; if something can be done prior to it spreading, why } \\
\text { isn't it being done? It freaks you out." (Interviewee 5, aged 72) }\end{array}$ \\
\hline $\begin{array}{l}\text { Lack of } \\
\text { information } \\
\text { and } \\
\text { knowledge }\end{array}$ & $\begin{array}{l}\text { Part of the reason } \\
\text { for the increased } \\
\text { levels of } \\
\text { emotional distress } \\
\text { seemed to be } \\
\text { attributed to a } \\
\text { lack of } \\
\text { understanding } \\
\text { and lack of } \\
\text { information } \\
\text { received } \\
\text { about active } \\
\text { surveillance. }\end{array}$ & $\begin{array}{l}\text { "If they had said what active surveillance is then perhaps I might have } \\
\text { understood it a bit better, but they just said we will keep an eye on it every } 6 \\
\text { months. You know, keeping an eye on it could mean a blood test, a meeting } \\
\text { with the consultant, another biopsy. I was in the dark and it is the not } \\
\text { knowing, the lack of information, that is what worries you". (Interviewee 13, } \\
\text { aged 71) }\end{array}$ \\
\hline $\begin{array}{l}\text { The need } \\
\text { for } \\
\text { additional } \\
\text { support in } \\
\text { the form of } \\
\text { a support } \\
\text { group }\end{array}$ & $\begin{array}{l}\text { The men } \\
\text { interviewed } \\
\text { explained their } \\
\text { access to Prostate } \\
\text { Cancer experts is } \\
\text { limited and } \\
\text { therefore access } \\
\text { to a group of men } \\
\text { also under active } \\
\text { surveillance would } \\
\text { be helpful. }\end{array}$ & $\begin{array}{l}\text { "You know, you see the hospital doctors very infrequently so for me I } \\
\text { always viewed my GP, who I have known for years, as my first port of call } \\
\text { when I needed to better understand things relating to active } \\
\text { surveillance and my tests and stuff. But the problem I found was, and I } \\
\text { don't mean to be rude, he [the GP] didn't know any more about active } \\
\text { surveillance than me so you are kind of left in this horrible place where no } \\
\text { one has the ability to answer your questions or fears so meeting up with } \\
\text { other chaps on active surveillance in a confidential and educationally } \\
\text { focused group would be a real coup for me" (Interviewee 12, aged 58). }\end{array}$ \\
\hline $\begin{array}{l}\text { The need } \\
\text { for } \\
\text { additional } \\
\text { support in } \\
\text { the form of } \\
\text { a website }\end{array}$ & $\begin{array}{l}\text { Men wanted to } \\
\text { play an active part } \\
\text { in helping } \\
\text { themselves and } \\
\text { would value self- } \\
\text { management } \\
\text { information in the } \\
\text { form of a } \\
\text { website. }\end{array}$ & $\begin{array}{l}\text { "If prostate cancer specific information was available on the web, then that } \\
\text { reassures people. Things like frequently asked questions, situations and } \\
\text { symptoms to look out for, advice on what you can do to help manage it } \\
\text { [prostate cancer], advice about diet, changes that I ought to be making. } \\
\text { Things of that nature really, things to allow me to self-manage this } \\
\text { [prostate cancer]" (Interviewee 1, aged 71). }\end{array}$ \\
\hline
\end{tabular}

\section{Implications for PROACTIVE development}

The results from this qualitative study indicate that men being managed with active surveillance would welcome specific additional psycho-educational support to help them better cope and manage with the burden of living with untreated prostate cancer. According to the data, a mixture of web-based support and group session support would be most appropriate.

Intervention Design 


\section{Key guiding principles}

Using the information gathered during the intervention planning phase, the research team developed a set of key guiding principles, in line with the PBA approach. The purpose of this is to summarise the design objectives and how these will be achieved, to facilitate quick and easy reference throughout the planning and development phase to guide and focus the decision making around intervention content and design(13). Table 4 outlines the three intervention design objectives along with the key features of the intervention designed to address each objective.

Table 4: Key Guiding Principles 
Intervention

design objective
Rationale for design objective and key features
1. To support men to manage the anxiety they experience due to being on active surveillance.
The group sessions should provide support with anxiety by providing reassurance and normative information about others' experiences, and encouragement in the development of coping skills (for example, social support mobilisation). The web component should complement the group sessions, enabling men to learn selfmanagement strategies to take control of their anxiety. The web component should also signpost men to further reliable information available online.
- All research conducted in the planning phase indicated emotional distress.

- The qualitative study with the target audience, and various previous interventions $(22-27,29)$ indicated group support may be beneficial.

- The qualitative study indicated a lack of reliable PCa and AS related information.
1. To

encourage and support a healthy lifestyle.
The web component should provide information about diet, physical activity and stress management to encourage a healthy lifestyle. Asking the men to set weekly goals could encourage them to utilise the information and implement changes to benefit their health. Relaxation techniques to be demonstrated in the group sessions, and the lifestyle information reinforced.
- Target audience in qualitative study requested selfmanagement tools/advice.
1. To maximise engagement in the programme.
In order to encourage participation from men who might usually feel uncomfortable participating, and to minimise withdrawal from the group sessions, the group sessions need to be facilitated in a way that encourages active participation, mutual understanding, respect and help-seeking behaviour (for example, demonstrating an interest for further information). To encourage men who might otherwise not participate the group facilitator needs to sensitively encourage patients to identify their emotional state and feelings.
- Important to maximise engagement in the programme to maximise change / improvements.

\section{Developing a logic model}

The MRC complex intervention guidelines(35) recommend the development of a logic model to outline the hypothesized causal mechanisms involved in bringing about change in men on AS for PCa. The logic model (Figure 1) demonstrates how we anticipate the intervention will result in improved psychological wellbeing. 
Figure 1: Logic Model

\section{Public and patient involvement}

Three Patient and Public Involvement (PPI) contributors with PCa were involved in the intervention planning and development process. The research team met with the contributors every 4-8 weeks to provide progress updates and gain feedback on ideas and written materials. PPI contributors reviewed and commented on the online and workshop content and were involved in all key decisions. The involvement of the PPI contributors ensured developing study materials were likely to be acceptable, understandable and relevant to the target audience.

\section{Result}

\section{The PROACTIVE prototype}

The prototype intervention was named PROACTIVE -'PROstate ACTIVE surveillance support'. The intervention consisted of two parts:

1.) An online programme consisting of six sessions designed to be completed on a weekly basis.

2.) A face-to-face group support programme with three sessions, spread across six weeks, held fortnightly and each lasting 60-90 minutes.

The web-based programme and the group support sessions interlink and are designed to run in parallel over 6 weeks, complementing each other; for example, the online sessions introduce topics that will be further discussed in the following group session, and the online sessions reinforce the information covered in previous group sessions. Figure 2 shows the intervention as a whole over the 6 week time period. See Table 5 for a detailed description of the session content.

Figure 2: The PROACTIVE Intervention

\section{The intervention}

Table 5 details the content of each of the web-based and face-to-face group sessions delivered over the 6-week period.

Table 5: The intervention 


\begin{tabular}{|c|c|c|c|c|c|}
\hline Week & $\begin{array}{l}\text { Delivery } \\
\text { mode }\end{array}$ & Session title & Content & $\begin{array}{l}\text { Why was this } \\
\text { included? }\end{array}$ & Target behaviour(s) \\
\hline 1 & $\begin{array}{l}\text { Web- } \\
\text { based }\end{array}$ & $\begin{array}{l}\text { Introduction } \\
\text { and physical } \\
\text { activity }\end{array}$ & $\begin{array}{l}\text { Introduction to the } \\
\text { website. } \\
\text { Information about active } \\
\text { surveillance, Prostate } \\
\text { Specific Antigen (PSA) } \\
\text { testing, prostate cancer in } \\
\text { general and prostate } \\
\text { cancer statistics with } \\
\text { printable information } \\
\text { sheets. } \\
\text { Section on physical } \\
\text { activity providing } \\
\text { information about the } \\
\text { benefits of increasing } \\
\text { physical activity and } \\
\text { ways to go about it. }\end{array}$ & $\begin{array}{l}\text { Target audience in } \\
\text { qualitative study } \\
\text { requested: } \\
\text { - reliable } \\
\text { information } \\
\text { - self- } \\
\text { management } \\
\text { tools/advice }\end{array}$ & $\begin{array}{l}\text { - Engagement } \\
\text { with the } \\
\text { program } \\
\text { - Increased PCa } \\
\text { knowledge } \\
\text { - Motivation to } \\
\text { increase } \\
\text { physical } \\
\text { activity }\end{array}$ \\
\hline 1 & $\begin{array}{l}\text { Face-to- } \\
\text { face } \\
\text { group } \\
\text { session }\end{array}$ & $\begin{array}{l}\text { Information, } \\
\text { reassurance } \\
\text { and } \\
\text { introduction } \\
\text { to lifestyle } \\
\text { information }\end{array}$ & $\begin{array}{l}\text { Provision of information } \\
\text { to ensure patients are } \\
\text { fully informed about their } \\
\text { condition and treatment } \\
\text { plan. Time for patients to } \\
\text { ask questions included. } \\
\text { Provision of reassurance } \\
\text { and comfort by } \\
\text { identifying areas of } \\
\text { concern related to active } \\
\text { surveillance, targeting } \\
\text { possible frustration } \\
\text { related to inadequate } \\
\text { information. } \\
\text { Introduction to lifestyle } \\
\text { (diet and exercise) } \\
\text { information. }\end{array}$ & $\begin{array}{l}\text { Target audience in } \\
\text { qualitative study } \\
\text { requested: } \\
\text { - reliable } \\
\text { information } \\
\text { - self- } \\
\text { management } \\
\text { tools/advice } \\
\text { - social support } \\
\text { from other men } \\
\text { on the AS } \\
\text { pathway }\end{array}$ & $\begin{array}{l}\text { - Engagement } \\
\text { with the } \\
\text { program } \\
\text { - Increased PCa } \\
\text { knowledge } \\
\text { - Motivation to } \\
\text { improve } \\
\text { lifestyle }\end{array}$ \\
\hline 2 & $\begin{array}{l}\text { Web- } \\
\text { based }\end{array}$ & Foods to eat & $\begin{array}{l}\text { Advice about foods to } \\
\text { eat. General healthy } \\
\text { eating advice, with some } \\
\text { specific prostate cancer } \\
\text { diet information. }\end{array}$ & $\begin{array}{l}\text { Target audience in } \\
\text { qualitative study } \\
\text { requested self- } \\
\text { management } \\
\text { tools/advice. }\end{array}$ & $\begin{array}{l}\text { - Improved } \\
\text { nutrition } \\
\text { knowledge } \\
\text { - Motivation to } \\
\text { improve diet }\end{array}$ \\
\hline 3 & $\begin{array}{l}\text { Web- } \\
\text { based }\end{array}$ & $\begin{array}{l}\text { Relaxation \& } \\
\text { Resilience } \\
\text { techniques }\end{array}$ & $\begin{array}{l}\text { Two relaxation } \\
\text { techniques described } \\
\text { with step-by-step } \\
\text { instructions. }\end{array}$ & $\begin{array}{l}\text { Target audience } \\
\text { reported: } \\
\text { - emotional } \\
\text { distress } \\
\text { - desire for self- } \\
\text { management } \\
\text { tools/advice } \\
\\
\text { Relaxation } \\
\text { techniques aim to } \\
\text { provide men with } \\
\text { self-management }\end{array}$ & $\begin{array}{l}\text { - Improved } \\
\text { confidence in } \\
\text { the self- } \\
\text { management } \\
\text { of emotional } \\
\text { distress } \\
\text { - Improved self- } \\
\text { management } \\
\text { of emotional } \\
\text { distress }\end{array}$ \\
\hline
\end{tabular}


tools to address

high levels of self-

reported emotional

distress.

$\begin{array}{ll}\text { Face-to- } & \text { Introduction } \\ \text { face } & \text { to stress } \\ \text { group } & \text { management } \\ \text { session } & \begin{array}{l}\text { and relaxation } \\ \text { / resilience } \\ \text { techniques }\end{array}\end{array}$

Discussion of issues and concerns related to lifestyle and active surveillance related information.
Target audience reported:

- emotional distress

- desire for selfmanagement tools/advice

- social support from other men on the AS pathway

- Improved confidence in the selfmanagement of emotional distress

- Improved selfmanagement of emotional distress

- Improved confidence in improving lifestyle

Target audience reported:

- emotional distress

- lack of reliable information

Improved PCa / AS related communication with friends and family may reduce emotional distress.

Improved communication in specialist consultations may help fill any gaps in knowledge or understanding.

\begin{tabular}{|c|c|c|c|}
\hline $\begin{array}{l}\text { Web- } \\
\text { based }\end{array}$ & $\begin{array}{l}\text { Thoughts and } \\
\text { feelings }{ }^{*}\end{array}$ & $\begin{array}{l}\text { Addresses distressing } \\
\text { thoughts and feelings the } \\
\text { men may be } \\
\text { experiencing. Provides } \\
\text { advice about how to } \\
\text { manage and/or reduce } \\
\text { these thoughts and } \\
\text { feelings. }\end{array}$ & $\begin{array}{l}\text { Target audience } \\
\text { reported: } \\
\text { - emotional } \\
\text { distress } \\
\text { - desire for self- } \\
\text { management } \\
\text { tools/advice }\end{array}$ \\
\hline
\end{tabular}

Partners included to:

- promote PCa/AS related communication
- Improved PCa related communication with family and friends

- Improved communication in specialist consultations to ensure patient questions are answered adequately

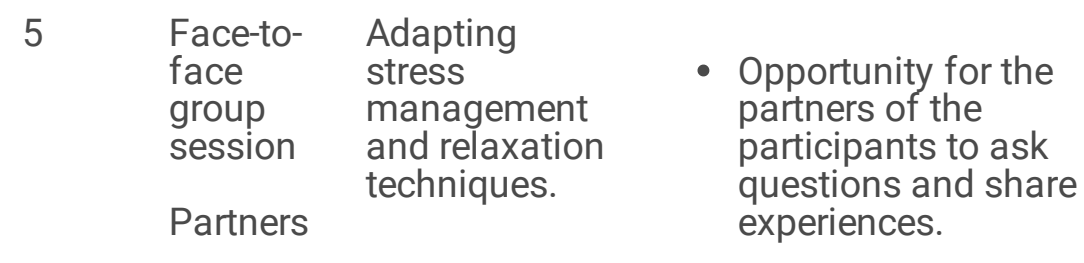




\begin{tabular}{|c|c|c|c|c|c|}
\hline & $\begin{array}{l}\text { invited } \\
\text { to the } \\
\text { first } 20 \\
\text { minutes } \\
\text { of this } \\
\text { session }\end{array}$ & & $\begin{array}{l}\text { Partners to leave the } \\
\text { session after } 20 \\
\text { minutes. } \\
\text { - Reinforcing and } \\
\text { adapting relaxation } \\
\text { and resilience } \\
\text { techniques for future } \\
\text { use. } \\
\text { - Discussion/feedback } \\
\text { about the } \\
\text { PROACTIVE } \\
\text { programme. } \\
\text { Opportunity for } \\
\text { participants to gain } \\
\text { clarity about } \\
\text { anything covered in } \\
\text { the programme. }\end{array}$ & $\begin{array}{l}\text { - to ensure gaps } \\
\text { in knowledge } \\
\text { and } \\
\text { understanding } \\
\text { are filled for } \\
\text { both the men } \\
\text { and their } \\
\text { partners } \\
\text { Reinforcement of all } \\
\text { that has been learnt } \\
\text { over the program to } \\
\text { provide confidence } \\
\text { in moving forward } \\
\text { with self- } \\
\text { management tools. } \\
\text { Provision of social } \\
\text { support from other } \\
\text { men on the AS } \\
\text { pathway. }\end{array}$ & $\begin{array}{l}\text { tools moving } \\
\text { forward } \\
\text { - Confidence in } \\
\text { PCA and AS } \\
\text { knowledge and } \\
\text { understanding }\end{array}$ \\
\hline 6 & $\begin{array}{l}\text { Web- } \\
\text { based }\end{array}$ & $\begin{array}{l}\text { Daily life; } \\
\text { money and } \\
\text { work }^{*}\end{array}$ & $\begin{array}{l}\text { Covers advice about } \\
\text { practical issues (for } \\
\text { example, paying for } \\
\text { hospital parking), and } \\
\text { provides information } \\
\text { about dealing with work } \\
\text { after receiving a } \\
\text { diagnosis. }\end{array}$ & $\begin{array}{l}\text { Practical advice to } \\
\text { aid self- } \\
\text { management. }\end{array}$ & $\begin{array}{l}\text { - Improved } \\
\text { confidence in } \\
\text { managing } \\
\text { diagnosis in } \\
\text { work }\end{array}$ \\
\hline $1-6$ & & $\begin{array}{l}\text { Goal and plan } \\
\text { setting / Goal } \\
\text { and plan } \\
\text { reviewing }\end{array}$ & $\begin{array}{l}1-3 \text { weekly goals, with a } \\
\text { plan to go with each one. } \\
\text { Goals and plans } \\
\text { reviewed on a weekly } \\
\text { basis. }\end{array}$ & $\begin{array}{l}\text { Goal setting } \\
\text { provides a way of } \\
\text { self-monitoring } \\
\text { progress and } \\
\text { provides some } \\
\text { accountability. }\end{array}$ & \\
\hline $1-6$ & & Web links & $\begin{array}{l}\text { Website links to useful } \\
\text { resources related to each } \\
\text { session. }\end{array}$ & $\begin{array}{l}\text { Target audience } \\
\text { reported a lack of } \\
\text { reliable information. } \\
\text { Links provide further } \\
\text { information from } \\
\text { credible sources. }\end{array}$ & \\
\hline
\end{tabular}

*These three online sessions could be completed in any order

\section{Think aloud interviews to refine PROACTIVE}

Identified by the PCaSO charity (Prostate Cancer Support Organisation), 2 men with prostate cancer took part in think aloud interviews. This process involved each participant working their way through the PROACTIVE prototype whilst simultaneously speaking aloud their thoughts about the programme. Statements such as 'can you tell me what you think about this page?' and 'can you tell me why you chose that option?' were used as prompts to elicit participants opinions on the intervention. Interviews were audio recorded, participant thoughts and opinions were collated and used to amend the prototype to be used in the pilot study. Table 6 provides a summary of these changes.

Table 6 Summary of changes from think aloud interviews 


\begin{tabular}{|c|c|}
\hline Comments from think aloud & Action \\
\hline $\begin{array}{l}\text { Various aesthetic suggestions were } \\
\text { made, for example, removing/adding } \\
\text { pictures, less information on each page, } \\
\text { centralising headings. }\end{array}$ & $\begin{array}{l}\text { All suggestions were discussed within the research team and the } \\
\text { majority were implemented. }\end{array}$ \\
\hline $\begin{array}{l}\text { Suggestion to add in a quick summary of } \\
\text { all sessions as part of the introduction. }\end{array}$ & Added as suggested. \\
\hline $\begin{array}{l}\text { Minor wording changes to information } \\
\text { sheets and sessions suggested. }\end{array}$ & Implemented as suggested. \\
\hline $\begin{array}{l}\text { Physical activity section needs to be } \\
\text { relevant to PCa. }\end{array}$ & $\begin{array}{l}\text { Physical activity advice was included, and recommendations in } \\
\text { line with NHS guidance. The research team added information to } \\
\text { explain how improving physical activity can improve wellbeing and } \\
\text { general health. }\end{array}$ \\
\hline $\begin{array}{l}\text { Physical activity session assumes all } \\
\text { participants are unfit, amend wording to } \\
\text { remove this assumption. }\end{array}$ & Implemented as suggested. \\
\hline Add more examples of goals. & Added as suggested. \\
\hline Add in the benefits of talking to others. & Added as suggested. \\
\hline $\begin{array}{l}\text { Section about talking to professionals } \\
\text { implies there will be problems. }\end{array}$ & Wording adjusted to remove implication. \\
\hline $\begin{array}{l}\text { Add statement that doctors / nurses will } \\
\text { not be embarrassed by certain topics. }\end{array}$ & Added as suggested. \\
\hline Make goal page printable. & Actioned as suggested. \\
\hline
\end{tabular}

\section{PROACTIVE ready for pilot study}

The amended intervention became the final version for pilot. Figure 3 below shows some screenshots from the webbased sessions.

Figure 3 PROACTIVE Screenshots

\section{Discussion}

\section{Summary}

This paper demonstrates how we used the PBA to develop an internet and group based psycho-educational behavioural intervention for men on AS for PCa. The process of gathering, understanding and utilising target-user needs and perspectives has long been viewed as essential within the eHealth research community (36-38). Intervention developers in the area of eHealth have undertaken this task in a variety of ways $(39,40)$, however, until the publication of the PBA there was no standardised approach or process to follow. Guided by the PBA the researchers gained a context-specific understanding of the intervention elements likely to be needed to maximise participant acceptability and engagement. 
Each component of our approach (see Table 1) added a valuable contribution to the development process. The systematic review and meta-analysis of depression and anxiety in prostate cancer provided a broad understanding of the prevalence of these conditions in PCa patients, and confirmed the dearth of literature specific to AS. Beginning to fill this gap in the literature, the cross-sectional survey on depression and anxiety in AS allowed us to narrow down the treatment pathway diversity in previous studies and focus on men on AS. Men in this survey displayed significant levels of distress, reinforcing the value of the proposed intervention. Reviewing existing interventions in the field provided a way of seeing what has and has not been successful in the past, and an understanding of the elements that may increase the success of the proposed intervention. The qualitative study gave us the opportunity to explore the supportive care needs of this user group in an in-depth way providing focussed direction for the intervention and a way of identifying any gaps.

Integrating the results from these 4 components we were able to create a set of key guiding principles. The key guiding principles summarised the design objectives and provided focus for decision making. Our logic model provided a visual representation of how the intervention might work, displaying the intervention ingredients and how these translate into the causal mechanisms likely to bring about change.

Armed with the understanding gained from the above mentioned processes we were able to create the prototype PROACTIVE intervention. The think-aloud interviews provided further clarity, and the minor changes made due to the results of these interviews improved our confidence in the intervention.

This methodological approach is rigorous but flexible. For other interventions the stages and processes may differ depending on the context of the intervention(41-45), for example, if there is already a large base of existing qualitative research, new qualitative research may not be necessary.

\section{Strengths, limitations and future research}

Treatment for PCa is a rapidly changing and advancing field, for example, medical technology and the accuracy of diagnostic tests continually being improved. For this reason PCa interventions (including PROACTIVE) would need to be updated regularly to stay current and accurate. The advantage of this development process is that it has produced a core product based on a rigorous transparent process with clear guiding principles that can easily be shared, adapted and updated, negating the need to repeatedly start from scratch.

The PBA recommends incorporating behavioural science into the development of interventions by integrating a 'theory-based' approach with the PBA processes as best practice. In this instance this was not possible due to time and resource constraints. Further research conducting theory-based processes, and mapping the findings to the intervention, identifying any gaps, would be beneficial to potentially strengthen the intervention.

\section{Conclusion}

This paper outlines the stages we followed using the PBA to develop the PROACTIVE intervention. The planning and development process is key to successful delivery of an appropriate accessible intervention. This meticulous description in a clinical setting using this rigorous but flexible method is a useful demonstration for others developing similar interventions.

\section{Declarations}

\section{Availability of data and materials}


The datasets supporting the conclusions of this article are included within the article and its additional files.

\section{Competing interests}

The authors declare that they have no competing interests.

\section{Funding}

Prostate Cancer UK, Grant/Award Number: PG14-023

\section{Authors' contributions}

SH: Part of the team that designed and developed PROACTIVE. Created the PROACTIVE prototype website. Drafted the paper.

AK: Part of the team that designed and developed PROACTIVE. Developed the content of the group sessions. Made substantial contributions to the paper with comments and advice.

HE: Made substantial contributions to the paper with comments and advice.

BS: Made substantial contributions to the paper with comments and advice.

BB: Made substantial contributions to the paper with comments and advice.

\section{Acknowledgements}

We would like to acknowledge Prostate Cancer UK for funding the study.

Professor George Lewith sadly passed away before publication. We would like to acknowledge him as the lead investigator for the PROACTIVE project. He is responsible for leading the team with design and development decisions.

Lastly, we would like to acknowledge Katherine Bradbury for offering advice and guidance with the Person-Based Approach.

\section{References}

1. Smittenaar CR, Petersen KA, Stewart K, Moitt N. Cancer incidence and mortality projections in the UK until 2035. Br J Cancer. 2016;115(9):1147-55.

2. Bray F, Ferlay J, Soerjomataram I, Siegel RL, Torre LA, Jemal A. Global cancer statistics 2018: GLOBOCAN estimates of incidence and mortality worldwide for 36 cancers in 185 countries. CA Cancer J Clin. 2018;68(6):394-424.

3. Bellardita L, Valdagni R, van den Bergh R, Randsdorp H, Repetto C, Venderbos LD, et al. How does active surveillance for prostate cancer affect quality of life? A systematic review. Eur Urol. 2015;67(4):637-45.

4. Watts S, Leydon G, Birch B, Prescott P, Lai L, Eardley S, et al. Depression and anxiety in prostate cancer: a systematic review and meta-analysis of prevalence rates. BMJ Open. 2014;4(3):e003901.

5. Watts S, Leydon G, Eyles C, Moore CM, Richardson A, Birch B, et al. A quantitative analysis of the prevalence of clinical depression and anxiety in patients with prostate cancer undergoing active surveillance. BMJ Open. 
2015;5(5):e006674.

6. Taylor KL, Hoffman RM, Davis KM, Luta G, Leimpeter A, Lobo T, et al. Treatment Preferences for Active Surveillance versus Active Treatment among Men with Low-Risk Prostate Cancer. Cancer Epidemiology Biomarkers \&amp;amp; Prevention. 2016;25(8):1240.

7. Biddle S. The psychological impact of active surveillance in men with prostate cancer: implications for nursing care. Br J Nurs. 2021;30(10).

8. Watts S. "They say most men die with and not from prostate cancer, but how do you live with it?" A qualitative interview study of the supportive care needs of patients on active surveillance. Patient Educ Couns. 2015.

9. McIntosh M, Opozda MJ, Evans H, Finlay A, Galvao DA, Chambers SK, et al. A systematic review of the unmet supportive care needs of men on active surveillance for prostate cancer. Psychooncology. 2019;28(12):230722.

10. Donachie K, Cornel E, Adriaansen M, Mennes R, Oort I, Bakker E, et al. Optimizing psychosocial support in prostate cancer patients during active surveillance. International Journal of Urological Nursing. 2020;14(3):115-23.

11. Parker PA, Davis JW, Latini DM, Baum G, Wang X, Ward JF, et al. Relationship between illness uncertainty, anxiety, fear of progression and quality of life in men with favourable-risk prostate cancer undergoing active surveillance. BJU Int. 2016;117(3):469-77.

12. Latini DM, Hart SL, Knight SJ, Cowan JE, Ross PL, Duchane J, et al. The relationship between anxiety and time to treatment for patients with prostate cancer on surveillance. J Urol. 2007;178(3 Pt 1):826-31. discussion 312.

13. Yardley L, Morrison L, Bradbury K, Muller I. The person-based approach to intervention development: application to digital health-related behavior change interventions. J Med Internet Res. 2015;17(1):e30.

14. Yardley L, Ainsworth B, Arden-Close E, Muller I. The personbased approach to enhancing the acceptability and feasibility of interventions. 2015.

15. van den Bergh RC, Essink-Bot ML, Roobol MJ, Wolters T, Schroder $\mathrm{FH}$, Bangma $\mathrm{CH}$, et al. Anxiety and distress during active surveillance for early prostate cancer. Cancer. 2009;115(17):3868-78.

16. Van den Bergh R, Essink-Bot ML, Robol MJ, Schroder FH, Bangma C, Steyerberg EW. Do anxiety and distress increase during active surveillance for low risk prostate cancer? J Urol. 2010;183:1786-91.

17. Burnet KL, Parker C, Dearnaley D, Brewin CR, Watson M. Does active surveillance for men with localized prostate cancer carry psychological morbidity? BJU Int. 2007;100(3):540-3.

18. Steineck G, Helgesen F, Adolfsson J, Dickman PW, Johansson JE, Norlén BJ, et al. Quality of life after radical prostatectomy or watchful waiting. N Engl J Med. 2002;347(11):790-6.

19. Zigmond AS, Snaith RP. The Hospital Anxiety and Depression Scale. Acta Psychiatr Scand. 1982;67:361-70.

20. NHS. The Information Centre for Health and Social Care. Health Survey for England 2005: Health of Older People. 2007.

21. Watts S. The assessment and management of anxiety and depression in prostate cancer patients being managed with active surveillance. 2014.

22. Parker PA, Pettaway CA, Babaian RJ, Pisters LL, Miles B, Fortier A, et al. The effects of a presurgical stress management intervention for men with prostate cancer undergoing radical prostatectomy. J Clin Oncol. 2009;27(19):3169-76. 
23. Penedo FJ, Dahn JR, Molton I, Gonzalez JS, Kinsinger D, Roos BA, et al. Cognitive-behavioral stress management improves stress-management skills and quality of life in men recovering from treatment of prostate carcinoma. Cancer. 2004;100(1):192-200.

24. Penedo FJ, Molton I, Dahn JR, Shen BJ, Kinsinger D, Traeger L, et al. A randomized clinical trial of group-based cognitive-behavioral stress management in localized prostate cancer: development of stress management skills improves quality of life and benefit finding. Ann Behav Med. 2006;31(3):261-70.

25. Carlson LE, Speca M, Patel KD, Goodey E. Mindfulness-based stress reduction in relation to quality of life, mood, symptoms of stress, and immune parameters in breast and prostate cancer outpatients. Psychosom Med. 2003;65(4):571-81.

26. Carlson LE, Speca M, Faris P, Patel KD. One year pre-post intervention follow-up of psychological, immune, endocrine and blood pressure outcomes of mindfulness-based stress reduction (MBSR) in breast and prostate cancer outpatients. Brain Behav Immun. 2007;21(8):1038-49.

27. Templeton H, Coates V. Evaluation of an evidence-based education package for men with prostate cancer on hormonal manipulation therapy. Patient Educ Couns. 2004;55(1):55-61.

28. Berglund G, Petersson LM, Eriksson KC, Wallenius I, Roshanai A, Nordin KM, et al. "Between Men": a psychosocial rehabilitation programme for men with prostate cancer. Acta Oncol. 2007;46(1):83-9.

29. Lepore SJ, Helgeson VS, Eton DT, Schulz R. Improving quality of life in men with prostate cancer: a randomized controlled trial of group education interventions. Health psychology: official journal of the Division of Health Psychology American Psychological Association. 2003;22(5):443-52.

30. Bailey DE, Mishel MH, Belyea M, Stewart JL, Mohler J. Uncertainty intervention for watchful waiting in prostate cancer. Cancer Nurs. 2004;27(5):339-46.

31. Chambers SK, Ferguson M, Gardiner RA, Aitken J, Occhipinti S. Intervening to improve psychological outcomes for men with prostate cancer. Psychooncology. 2013;22(5):1025-34.

32. Kazer MW, Bailey DE Jr, Sanda M, Colberg J, Kelly WK. An Internet intervention for management of uncertainty during active surveillance for prostate cancer. Oncol Nurs Forum. 2011;38(5):561-8.

33. Osei DK, Lee JW, Modest NN, Pothier PK. Effects of an online support group for prostate cancer survivors: a randomized trial. Urol Nurs. 2013;33(3):123-33.

34. Weber BA, Roberts BL, Resnick M, Deimling G, Zauszniewski JA, Musil C, et al. The effect of dyadic intervention on self-efficacy, social support, and depression for men with prostate cancer. Psychooncology. 2004;13(1):4760.

35. Craig P, Dieppe P, Macintyre S, Michie S, Nazareth I, Petticrew M. Developing and evaluating complex interventions: the new Medical Research Council guidance. Int J Nurs Stud. 2013;50(5):587-92.

36. Pagliari C. Design and Evaluation in eHealth: Challenges and Implications for an Interdisciplinary Field. J Med Internet Res. 2007;9(2):e15.

37. Baker TB, Gustafson DH, Shah D. How Can Research Keep Up With eHealth? Ten Strategies for Increasing the Timeliness and Usefulness of eHealth Research. J Med Internet Res. 2014;16(2):e36.

38. van Gemert-Pijnen JEWC, Nijland N, van Limburg M, Ossebaard HC, Kelders SM, Eysenbach G, et al. A Holistic Framework to Improve the Uptake and Impact of eHealth Technologies. J Med Internet Res. 2011;13(4):e111.

39. Van Velsen L, Wentzel J, Van Gemert-Pijnen JEWC. Designing eHealth that Matters via a Multidisciplinary Requirements Development Approach. JMIR Res Protoc. 2013;2(1):e21. 
40. Yen P-Y, Bakken S. Review of health information technology usability study methodologies. J Am Med Inform Assoc. 2012;19(3):413-22.

41. Band R, Hinton L, Tucker KL, Chappell LC, Crawford C, Franssen M, et al. Intervention planning and modification of the BUMP intervention: a digital intervention for the early detection of raised blood pressure in pregnancy. Pilot Feasibility Stud. 2019;5:153.

42. Band R, Bradbury K, Morton K, May C, Michie S, Mair FS, et al. Intervention planning for a digital intervention for self-management of hypertension: a theory-, evidence- and person-based approach. Implement Sci. 2017;12(1):25.

43. Morton K, Ainsworth B, Miller S, Rice C, Bostock J, Denison-Day J, et al. Adapting Behavioral Interventions for a Changing Public Health Context: A Worked Example of Implementing a Digital Intervention During a Global Pandemic Using Rapid Optimisation Methods. Front Public Health. 2021;9:668197.

44. Muller I, Santer M, Morrison L, Morton K, Roberts A, Rice C, et al. Combining qualitative research with PPI: reflections on using the person-based approach for developing behavioural interventions. Res Involv Engagem. 2019;5:34.

45. Bradbury K, Steele M, Corbett T, Geraghty AWA, Krusche A, Heber E, et al. Developing a digital intervention for cancer survivors: an evidence-, theory- and person-based approach. NPJ Digit Med. 2019;2:85.

\section{Figures}

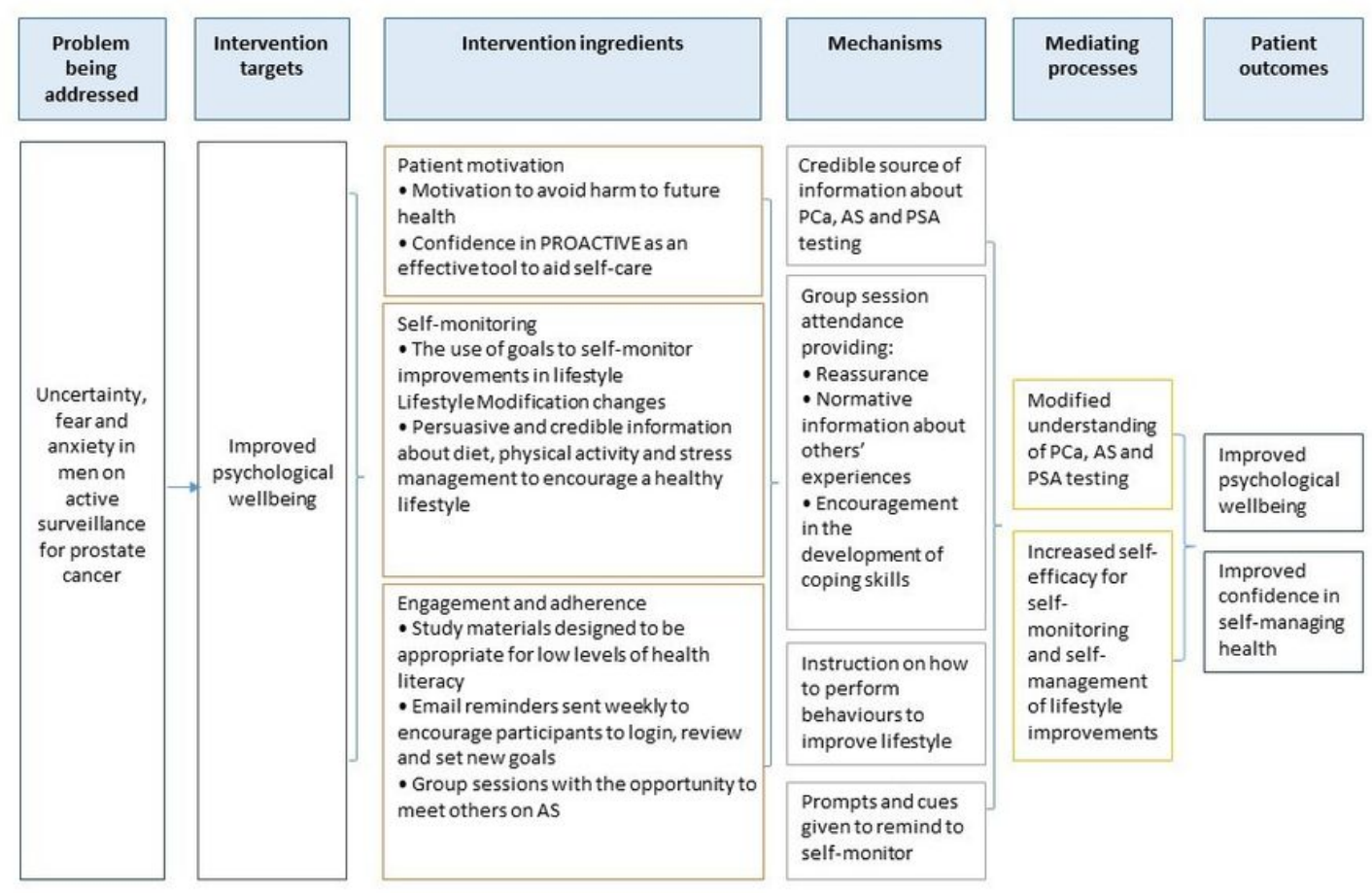

\section{Figure 1}

Logic Model 

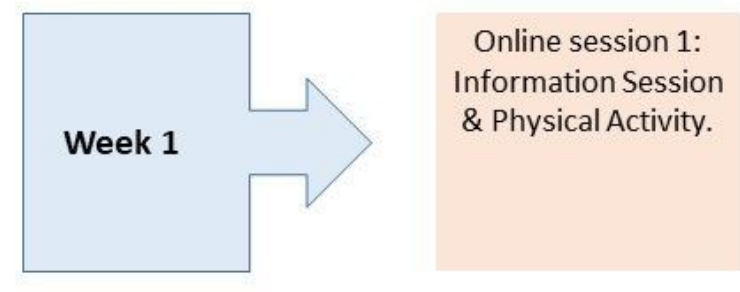

\& Physical Activity.
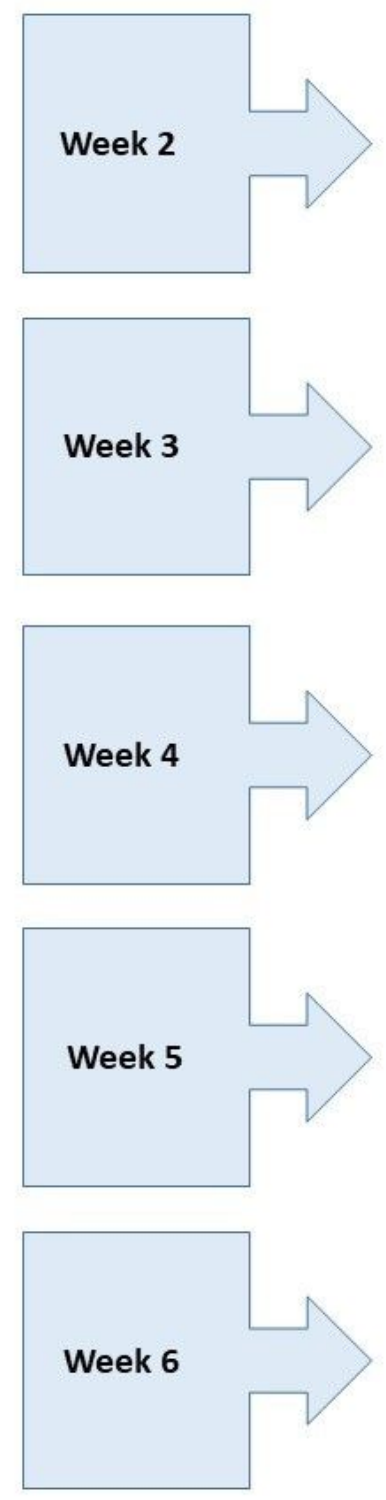

Online session 2:

Lifestyle Session.

Online session 3: Relaxation techniques session.

Online session 4: Choice of session (talking to others, managing thoughts and feelings, or practical issues.

Online session 5: Choice of session (talking to others, managing thoughts and feelings, or practical issues. Choice of session (talking to others, managing thoughts and feelings, or practical issues.
Online session 6:

\section{Figure 2}

The PROACTIVE Intervention

Group session:

Adapting stress

management and

relaxation

techniques. Partners included for part of session.
Group session: reassurance and introduction to lifestyle information. Introduction to stress management and relaxation / resilience techniques. 


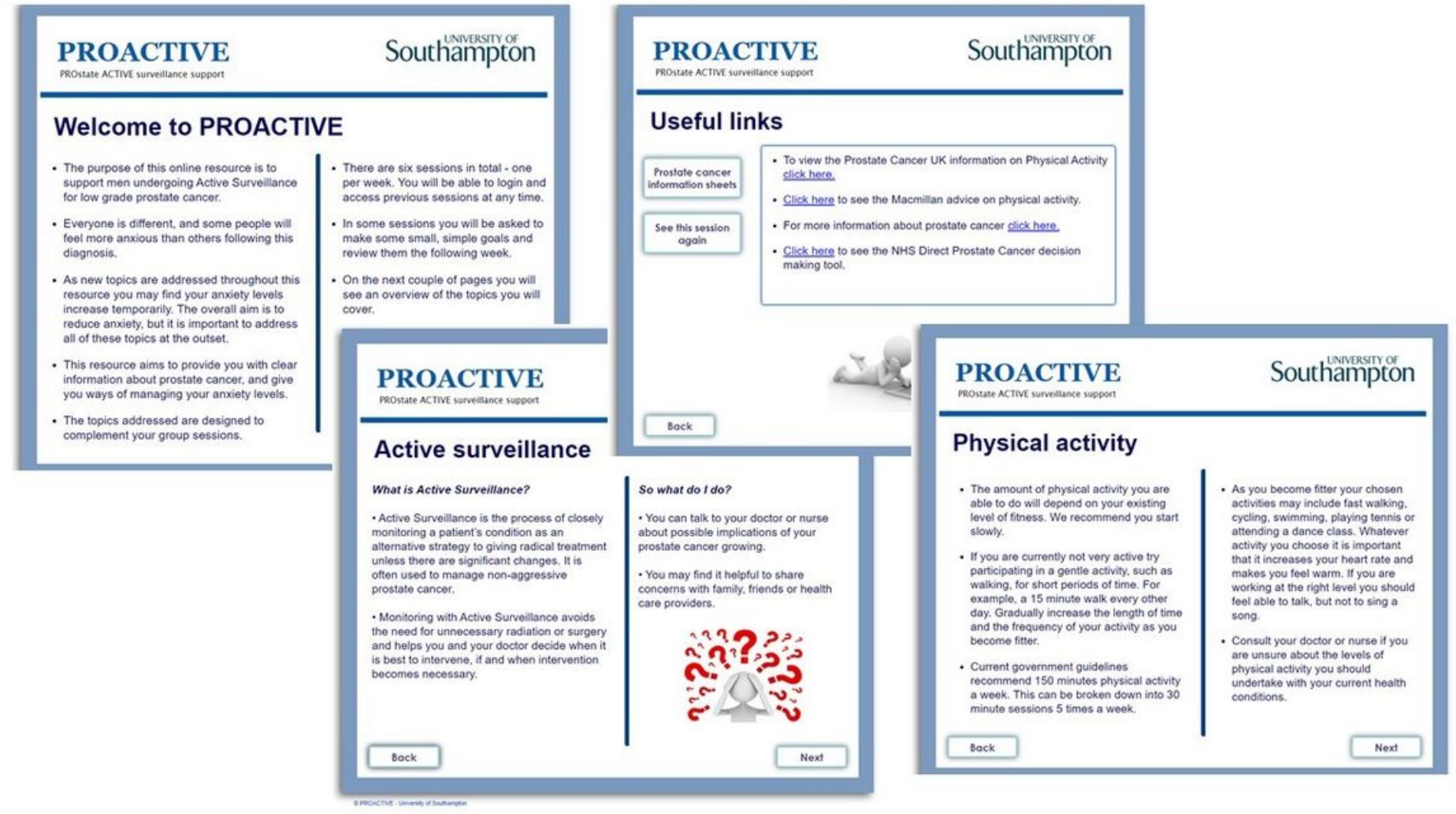

Figure 3

PROACTIVE Screenshots 